\title{
Distribution of Glutathione Peroxidase Activity in Fish
}

\author{
Takeshi Nagai, ${ }^{*} 1, \uparrow 1, \uparrow 2$ Junji Inada, ${ }^{* 2}$ Moritsugu Hamada, ${ }^{* 1}$ \\ Norihisa Kai, ${ }^{* 1}$ Yasuhiro Tanoue, ${ }^{* 1}$ Yoshio Kaminishi, ${ }^{* 1}$ \\ Hisaki Nakagawa, ${ }^{* 3}$ Kazuhiro Fujiki ${ }^{* 3}$ Miki Nakao*3 \\ and Tomoki Yano*3 \\ *1Department of Food Science and Technology, National Fisheries University, \\ Shimonoseki, Yamaguchi 759-6595, Japan \\ *2Royal Co., Ltd, 3-28-5 Naka, Fukuoka 816-0093, Japan \\ ${ }^{*}$ Faculty of Agriculture, Kyushu University, Fukuoka 812-8581, Japan \\ (Received February 6, 1998)
}

Key words: glutathione peroxidase, distribution, Japanese sea-bass, liver, intestine, ordinary muscle, yellowtail, horse mackerel

Aerobic living cells produce reactive oxidants such as super-oxide anion, hydrogen peroxide, and singlet oxygen. These metabolites are toxic to the cells by causing the oxidation of unsaturated lipids, amino acids, and nucleic acids. To protect the cells against these toxic oxidants, it is known to exist several enzymes removing these reactive oxidants, such as catalase (EC 1.11.1.6), superoxide dismutase (EC 1.15.1.1), and glutathione peroxidase (EC 1.11.1.9). Especially, glutathione peroxidase (GSH-Px) acts on both hydrogen peroxide and organic peroxides. Although GSH-Px activity has been determined on homogenates from various fish tissues, ${ }^{1-12)}$ only limited information has been obtained for the organ distribution of the enzyme in fish.

We described in this paper the distribution of GSH-Px activity of ten organs and tissues in three fish: Horse mackerel Trachurus japonicus (body weight, $0.2-0.5 \mathrm{~kg}$ ), Japanese sea-bass Lateolabrax japonicus $(0.8-1.2 \mathrm{~kg})$, and yellowtail Seriola quinqueradiata $(1.3-1.6 \mathrm{~kg})$.

Samples were weighed and then homogenized with three volumes of $50 \mathrm{~mm}$ sodium phosphate buffer ( $\mathrm{pH} \mathrm{7.0)}$ containing $2 \mathrm{~mm}$ phenylmethylsulphonyl fluoride, $4 \mathrm{~mm} 2-\mathrm{mer}-$ captoethanol (2-ME), and $1 \mathrm{mM}$ ethylenediaminetetraacetic acid (EDTA). The homogenates were centrifuged at $30,000 \times g$ for $30 \mathrm{~min}$, and then the supernatants were dialyzed against $10 \mathrm{~mm}$ sodium phosphate buffer $(\mathrm{pH} 7.0)$ containing $4 \mathrm{~mm} 2-\mathrm{ME}$ and $1 \mathrm{mM}$ EDTA. The dialysate was used as an enzyme solution.

The assay of enzymic activity was carried out by measuring the decrease in NADPH at $340 \mathrm{~nm}$ using the modified method of Little et al. ${ }^{13)}$ The reaction mixture $(0.5 \mathrm{~m} l)$ contained $32 \mathrm{~mm}$ sodium phosphate buffer (pH 7.0), $0.64 \mathrm{mM}$ $\mathrm{NaN}_{3}, 1.28 \mathrm{mM}$ EDTA, 0.13 unit glutathione reductase (EC 1.6.4.2 from yeast), $0.65 \mathrm{~mm}$ glutathione [reduced form (GSH)], $0.097 \mathrm{mM}$ NADPH, $0.16 \mathrm{~mm} t$-butyl hydroperoxide (TBH), and an appropriate amount of en- zyme. The reaction was started by the addition of TBH. The enzyme activity was defined as nmol NADPH oxidized per min per mg protein.

The protein concentration was measured by the method of Lowry et al. ${ }^{14)}$ using bovine serum albumin as a standard.

The distribution of GSH-Px activity in the fish is shown in Table 1. The Japanese sea-bass liver showed a remarkably high activity, and the activity was also shown in the kidney and spleen. In yellowtail, the liver exhibited the highest activity, followed by the spleen, kidney, heart, and stomach. In horse mackerel, the activity was detected in many organs and tissues. The spleen displayed the highest activity, and relatively high activity was shown in the heart, liver, brain, and kidney. The activity also occured in the pyloric caeca. Among the organs and tissues of all the fish examined, no activity was detected in the intestine and ordinary muscle. These results suggest that this enzyme acts on hydrogen peroxide and organic peroxides produced in the living cells. High GSH-Px activity must be necessary especially in the aerobic hepatic cells where a large amount of hydrogen peroxide would be produced through oxidation-reduction reactions.

Rana and Singh ${ }^{7)}$ reported the activties in the liver and kidney of two fresh water fishes (Channa punctatus and Clarias batrachus), and these activities were in the range of $10-48 \mathrm{nmol} / \mathrm{min} \cdot \mathrm{mg}$ protein. Watanabe et al. ${ }^{11)}$ reported the activities in the muscles of skipjack tuna and Japanese jack mackerel to be 3.26 and $2.28 \mathrm{nmol} / \mathrm{min} \cdot \mathrm{mg}$ protein, respectively. The values of these activities were lower than those of our results. On the other hand, Nakano et $a l .{ }^{12)}$ reported the activity in carp hepatopancreas to be $545.82 \mathrm{nmol} / \mathrm{min} \cdot \mathrm{mg}$ protein. Petrivalský et al. ${ }^{15)}$ reported the activity in rainbow trout liver to be $2452 \pm 352 \mathrm{nmol} / \mathrm{min} \cdot \mathrm{mg}$ protein. These values were much higher than those of our results. This may be partly

${ }^{t 1}$ To whom all correspondence should be addressed. Takeshi Nagai, Department of Food Science and Technology, National Fisheries University, Shimonoseki, Yamaguchi 759-6595, Japan. Tel: (81) (832) 86-5111, Fax: (81) (832) 86-7434. E-mail: machin@ ish-L.ac.jp

${ }^{\text {t2 }}$ Present Address: Faculty of Agriculture, Kyushu University, Fukuoka 812-8581, Japan. E-mail: machin@agr.kyushu-u.ac.jp 
Table 1. Tissue distribution of glutathione peroxidase activity in several fish

\begin{tabular}{|c|c|c|c|c|c|c|c|c|c|c|}
\hline \multirow{3}{*}{ Species } & \multicolumn{10}{|c|}{ Activity (nmol/min $\cdot \mathrm{mg}$ protein) } \\
\hline & \multicolumn{10}{|c|}{ Tissues } \\
\hline & B & $\mathbf{L}$ & $\mathbf{K}$ & $\mathbf{H}$ & I & $\mathbf{P}$ & ST & SP & 0 & $\mathbf{E}$ \\
\hline Japanese sea-bass & ND & $865.5 \pm 10.5$ & $148.0 \pm 5.2$ & ND & $\mathrm{ND}$ & ND & ND & $21.2 \pm 0.5$ & $\mathrm{ND}$ & - \\
\hline Yellowtail & ND & $146.8 \pm 4.9$ & $76.1 \pm 3.1$ & $66.3 \pm 2.2$ & $\mathrm{ND}$ & ND & $5.3 \pm$ & $83.3 \pm 3.0$ & ND & - \\
\hline Horse mackerel & $168.8 \pm 5.9$ & $172.2 \pm 6.4$ & $96.8 \pm 2.8$ & $262.9 \pm 4.8$ & ND & $56.4 \pm 1.4$ & ND & $370.9 \pm 7.3$ & ND & ND \\
\hline
\end{tabular}

Mean \pm SD $(n=5)$. ND: not detected.

B: Brain, L: Liver, K: Kidney, H: Heart, I: Intestine, P: Pyloric caeca, ST: Stomach, SP: Spleen, O: Ordinary muscle, E: Egg.

due to different conditions used for each enzyme assay and preparation of the enzyme.

This enzyme distributed in many organs and tissues of fish as well as mammals. ${ }^{1,5,8,10,12)}$ Especially in the liver to protect the cells against the large quantities of hydrogen peroxides produced by oxidation-reduction reactions, it seems that GSH-Px acts to guard the cells against these peroxides and then its activity is higher than those of other organs.

Further work is ongoing to purify GSH-Px and elucidate its detailed enzymological properties in fish.

\section{References}

1) A. Aksnes and L. R. Njaa: Comp. Biochem. Physiol., 69B, 893896 (1981).

2) J. W. Hilton, P. V. Hodson, and S. J. Slinger: J. Nutr., 110, 25272535 (1980).

3) F. Mazeaud, J. Maral, and A. M. Michelson: Biochem. Biophys. Res. Commun., 86, 1161-1168 (1979).

4) H. A. Poston, G. F. Combs, Jr., and L. Leibovitz: J. Nutr., 106,
892-904 (1976)

5) M. E. Tappel, J. Chaudiere, and AL L. Tappel: Comp. Biochem. Physiol, 73B, 945-949 (1982).

6) J. Wdzieczak, G. Zaleśna, A. Bartkowiak, H. Witas, and W. Leyko: Comp. Biochem. Physiol., 68B, 357-358 (1981).

7) S. V. S. Rana and R. Singh: Ichthyol. Res., 43, 223-229 (1996).

8) D. M. E. Otto and T. W. Moon: Fish. Physiol. Biochem., 15, 349358 (1996).

9) M. S. Parihar, T. Javeri, T. Hemnani, A. K. Dubey, and P. Prakash: J. Therm. Biol., 22, 151-156 (1997).

10) S. Kolayli, M. Arikan, D. Uzunosmanoglu, B. Vanizor, E. Kiran, and R. Sagban: Turkish. J. Zool., 21, 171-173 (1997).

11) F. Watanabe, M. Goto, K. Abe, and Y. Nakano: J. Food Sci, 61, 734-735, 782 (1996)

12) T. Nakano, M. Sato, and M. Takeuchi: J. Food Sci., 57, 1116-1119 (1992).

13) C. Little, R. Oinescu, K. G. Reid, and P. J. O'Brien: J. Biol. Chem., 245, 3632-3636 (1970).

14) O. H. Lowry, N. J. Rosebrough, A. L. Farr, and R. J. Randall: $J$. Biol. Chem., 193, 265-275 (1951).

15) M. Petřivalskŷ, M. Machala, K. Nezveda, V. Piačka, Z. Svobodovâ, and P. Drábek: Environ. Toxicol. Chem., 16, 14171421 (1997). 